\title{
Supplementary pension schemes: needs, possibilities and problems with evaluation from the perspective of an individual saver ${ }^{2}$
}

\begin{abstract}
Summary
The purpose of this article is to identify the scope of information (both qualitative and quantitative) relating to pension products, necessary to evaluate their operation by individual saver and subsequently to compare this scope with the information provided to customers by financial institutions. The research relies on an analysis of available literature, documents and reports of pension institutions as well as the legal acts which govern the pension scheme and the financial market. The analysis of the situation in Poland led to the identification, in the final part of the report, of possible future changes in the information policies and of restraints, which follow from the nature of the products offered and the level of complexity of the supplementary schemes.
\end{abstract}

1 Instytut Statystyki i Demografii, Szkoła Główna Handlowa w Warszawie, ul. Madalińskiego 6/8 pok. 221, 02-513 Warszawa; adres elektroniczny autorki: jrutec@sgh.waw.pl, ORCID — 0000-00022509-8599.

2 The research was financed from research grant number UMO-2016/21/D/HS5/03905 from the National Science Centre in Poland. 
Key words: pension scheme, supplementary old-age security, occupational pension schemes, individual retirement accounts, individual retirement savings accounts

\section{Introduction}

Supplementary pension schemes are a necessary element of the social security system in view of increasingly lower replacement rates from mandatory schemes, which have been subjected to in-depth, systemic and parametric reforms over recent decades. Consequently, a pension gap arises, which reflects the difference between the desired income and the income received from base pension system, which may be supplemented with an additional, either collective or individual, pension scheme. It is assumed (Góra, Rutecka, 2013; Rutecka, 2014) that a supplementary pension system should be universal, transparent (both in terms of the product structure and the structure of the entire system), effective and cheap. It should also feature stability, flexibility and should yield additional savings of long-term nature and support the economic growth and increased social welfare.

The said qualities are sometimes difficult to reconcile, especially when it comes to simultaneous universality, adaptation to individual needs of each potential participant, flexibility and transparency. Consequently, even developed markets offering supplementary pension schemes, which operate in Western Europe, are characterised by high complexity and multi-dimensional lack of transparency (Allgayer et al., 2016), which makes it difficult to move around them for an individual customer.

The level of complexity of supplementary pension products may be analysed using several dimensions (Turner, 2013; Rutecka, 2014; Chłon-Domińczak, Góra, Rutecka, 2016a):

- the complexity of the architecture of an additional pension system due to the availability of a number of institutional forms (employee and individual schemes, solutions addressed to various groups of recipients);

- the complexity of the product structure, which occurs where various products are offered by different financial institutions;

- the complexity of financial mechanisms used in pension products;

- the complexity of the agreement, which consists in the inclusion of numerous additional documents affecting its provisions;

- the complexity of the system of fees associated with the pension products;

- complexity resulting from the characteristics and/or size of the tax incentives used.

The multi-dimensional complexity of supplementary pension systems is a direct consequence of offering a broad range of financial products (pension funds, cash pension schemes, unit-linked life insurance, investment funds, bank accounts or securities 
accounts). All of them are offered on the financial market, which is the most complex and the least transparent of all goods and services markets (Rajnes, 2003).

At this point, it should be emphasised that the majority of the supplementary insurance markets are characterised by a complex architecture due to a voluntary nature of this element of the pension system, which is a consequence of the need to adapt the supplementary pension products to individual needs of the savers. The third pillar should supplement the base pension system, making it more flexible (Żukowski, 1997; Góra, Rutecka, 2013). The required flexibility of a product means that there are no uniform, fully standardised solutions and various financial mechanisms can be offered, with the State regulations in this respect being minimal. Therefore, the market features quite considerable freedom to word the contractual provisions. The legal regulations usually indicate the types of institutions, which may offer individual pension schemes, the general forms of products under such solutions and the limits of contributions, if these are subject to a tax relief or are funded by the employer and/or from the state budget. This situation makes it almost impossible for an individual saver to take an optimal decision (Prast, van Soest, 2015).

Where individual persons have different preferences as to the type of financial product, the level of contributions, the period of saving and form of payment of funds, the high complexity of the supplementary pension market is common. All major international analyses and comparative reports on supplementary pension schemes indicate a great variety and considerable deviations in the architecture and operation of the third pillar in the countries subject to analysis (Szumlicz, Żukowski, 2004; European Commission, 2010; OECD, 2012; Oxera, 2013; Berthon et al., 2014; OECD, 2015; Klages, Viver, 2015; Allgayer et al., 2016). Ever more often attention is given to the fact that such international comparability of simplified statistics does not offer a full view of the specific nature of operation of each pension market. The actual complexity of the markets and a broad range of risks, which the savers face, require the involvement of the State and adoption of additional regulations to be observed by the service providers (Paklina, 2016).

Even complex architectural pension systems may operate properly if they are transparent. With respect to the third pillar, this applies to the transparency of the rules of operation regarding supplementary pension schemes, the characteristics of the tax incentives offered or access to information (particularly comparative data) about the individual pension schemes on offer, their investment results and the cost level. In most countries, the official statistics consist in publication of aggregate data concerning the number of schemes/accounts operated, the value of assets or the average amount of contributions and the account balance (OECD, 2012; Oxera, 2013; Berthon et al., 2014; Klages, Viver, 2015; Allgayer et al., 2016). However, there are no official and impartial rankings of public institutions, which would inform individuals about the qualities of the full offer of products, the rate of return and level of cost of each of the available pension products. In this respect, additional pension systems are entirely non-transparent for an individual customer, even though such an aggregate approach to the creation of statistics 
facilitates and sometimes even enables comparisons between countries. In this approach, however, the saver's needs are disregarded. The saver, who is not adequately informed about the third pillar and about products operated within its framework, may not be willing to participate in this part of the system or may take sub-optimal decisions regarding their pension. Hence, a policy of adequate information provided to individuals is essential for proper development of the supplementary pension market.

The article presents an analysis of the information policy implemented on the supplementary pension system market in Poland. Deficiencies resulting from failure to satisfy the need for information among the customers will be identified and changes will be recommended in the information policy to be implemented on the Polish pension market. The analysis is based on a review of literature, documents and reports of pension institutions as well as the legal acts, which govern the pension system and the financial market.

\section{Complexity of Polish supplementary pension system}

The pension system in Poland consists of several elements (pillars), of which the supplementary pension system (employee pension schemes and individual pension accounts) will become increasingly more important in the coming years and decades. This is a consequence of the decreasing replacement rate (on the assumption that the existing pension age is maintained) as a result of pension reform made in 1999. The reform changed the formula for calculation of the pension from a defined benefit (DB) to a defined contribution (DC), where the value of pension depends on the accumulated capital/pension eligibility (paid-in contributions) and the pensionable age. In the near future, the compulsory pension system will supply the base benefit only, which will need to be supplemented with income from additional forms of pension saving, both collective (occupational) and individual.

The third (supplementary) pillar of Polish pension system consists of two elements: the individual part and the part organised by the employer. The Employee Pension Schemes (EPS; pracownicze programy emerytalne-PPE) were the earliest to arise (in 1999) and may operate in the form of a collective (group) unit-linked life insurance (the most popular form), an agreement for contribution payment to an investment fund, an employee pension fund and foreign management. The individual pension schemes may operate in the form of individual retirement accounts (indywidualne konto emerytalne-IKE) established in 2004 or individual retirement savings accounts (indywidualne konto zabezpieczenia emerytalnego-IKZE) implemented in 2012 which differ by the limit of contributions paid and the type of tax incentives offered. These are the only forms dedicated to an individual recipient, which are characterised by exemption from capital income tax and IKZE offers an additional privilege of the possibility to deduct the contribution from the taxable base and preferential taxation at pay-outs.

Despite considerable tax incentives and clear economic benefits from the accumulation of funds in individual pension schemes, IKE and IKZE are not particularly popular among 
Poles. At the end of 2017, only 5.8\% of professionally active Poles held an individual pension account, and $4.2 \%$ - an individual pension security account.

Table 1. Architecture of supplementary pension system in Poland

\begin{tabular}{|c|c|c|c|}
\hline & PPE & IKE & IKZE \\
\hline Forms & $\begin{array}{l}\text { - unit-linked group life } \\
\text { insurance } \\
\text { - investment fund } \\
\text { - employee pension fund } \\
\text { - foreign management }\end{array}$ & \multicolumn{2}{|c|}{$\begin{array}{l}\text { — unit-linked life insurance } \\
\text { — investment fund } \\
\text { — account with a brokerage house } \\
\text { — bank account } \\
\text { — voluntary pension fund }\end{array}$} \\
\hline $\begin{array}{l}\text { Type of } \\
\text { incentive }\end{array}$ & $\begin{array}{l}\text { - basic contribution paid by } \\
\text { the employer } \\
\text { - exemption from the capi- } \\
\text { tal gains tax }\end{array}$ & $\begin{array}{l}\text { - exemption from } \\
\text { the capital gains } \\
\text { tax }\end{array}$ & $\begin{array}{l}\text { - deduction of contribution } \\
\text { from taxable base } \\
\text { - exemption from capital } \\
\text { gains tax } \\
\text { - preferential tax on the } \\
\text { benefit }(10 \%)\end{array}$ \\
\hline $\begin{array}{l}\text { Contribution } \\
\text { limit }\end{array}$ & $\begin{array}{c}7 \% \text { of salary (employer) } \\
450 \% \text { of average salary } \\
\text { (employee) }\end{array}$ & $\begin{array}{c}300 \% \text { of average } \\
\text { salary }\end{array}$ & $120 \%$ of average salary \\
\hline Pension age & 60 & 60 & 65 \\
\hline $\begin{array}{l}\text { Forms of } \\
\text { payment }\end{array}$ & $\begin{array}{l}\text { - lump sum } \\
\text { - instalments }\end{array}$ & $\begin{array}{l}\text { - lump sum } \\
\text { — instalments }\end{array}$ & $\begin{array}{l}\text { - lump sum } \\
\text { - instalments }\end{array}$ \\
\hline
\end{tabular}

Source: own elaboration.

This situation may result from numerous reasons. One of them is a high level of complexity of the Polish supplementary pension system according to financial products and its providers, especially in individual part. The voluntary character of the third pillar products and their almost non-existent standardisation means that contracts may include a wide variety of entirely different, supplementary options, depending on the saver's preferences. Even though certain minimum requirements for the offer of IKE and IKZE are stipulated in the law (Ustawa $z$ dnia 20 kwietnia 2004 r. o indywidualnych kontach emerytalnych...), they include a general indication only of the financial mechanism, type of provider, the contribution limits, types of tax incentives, conditions (mainly age-related) for starting and ending the saving, and restrictions on cancellation and transfer fees. The agreements offered on the market do not differ, except for the abovementioned features, from standard products available outside the third pillar pension market.

Taking into account the desirable qualities of a pension product (Góra, Rutecka, 2013; Rutecka, 2014), namely: simplicity and comprehensibility, transparency, effectiveness (in terms of costs and investment results), proper risk-sharing, protection against longevity 
risk, flexibility and tax benefits, products offered in the supplementary pension system in Poland do not currently display most of the aforesaid qualities. The majority of them are neither simple nor comprehensible for the potential buyer. The market is not transparent and it is difficult to evaluate its investment and cost-effectiveness. The products usually lack any investment guarantees and most of them (apart from bonds indexed for inflation) do not guarantee that the real value of the accumulated funds will be maintained. They also do not offer protection against the longevity risk, as third pillar funds are usually paid out as a lump sum. However, the market is flexible, mostly in terms of adjustment of the level of contributions and investment policy to individual needs, also with regard to the possibility to change the pension product and its provider at the stage of accumulation of the funds.

\section{Problematic evaluation of supplementary pension schemes}

Polish supplementary pension market is non-transparent for the savers and, consequently, potential and actual savers find it extremely difficult to compare the available products and to select an offer, which suites them most. These problems are additionally enhanced by:

- the complicated language used in agreements for individual pension accounts (IKE and IKZE), their complexity and lack of transparency,

- low pension-related awareness and insufficient financial knowledge and competence of Poles,

- inadequate information policy on the pension market.

While a substantial number of Poles (58\%) has problems to assess the impact of inflation on real interest rates of bank deposits (Instytut Wolności and Raiffeisen Polbank, 2014), the purchase of a product dedicated to saving funds for old age requires that they compare instruments of much higher level of complexity (unit-linked insurance, a range of investment and pension funds, bank accounts and offers of brokerage houses), which they usually do not understand. It is not only the economic mechanism that is incomprehensible, but also the language of contractual provisions.

The literature in the area offers some works on the research of transparency and comprehensibility of utility texts (e.g. Pisarek, 1969; Broda, Ogrodniczuk, Nitoń, Gruszczyński, 2014), but no exhaustive research has been done on the comprehensibility of provisions of contracts on individual pension products. In Poland, the first attempts at studying the comprehensibility of pension product agreements consisted of analysing several sample IKE and IKZE products (Chłoń-Domińczak, Góra, Rutecka, 2016b). Although the study did not cover the entire market offer, it offered some picture of the level of difficulty of the language used in financial agreements.

The research done by Chłoń-Domińczak, Góra and Rutecka (2016b) showed that the language used in the insurance contracts was comprehensible for people who completed bachelor's studies, as a minimum (text difficulty class: score 5 on a 7-point scale) and completed minimum 13-15 years of education. The language of provisions 
of other agreements (e.g. agreements on IKE/IKZE in the voluntary pension fund) is slightly simpler, comprehensible for people with secondary education or considerable life experience (difficulty class 4). For the sake of comparison, the level of difficulty of articles concerning the pension system, posted on the home page of the mojaemerytura.pl website, are classified as difficulty class 4 , and so are the information materials for people interested in pension saving posted on the websites of the Polish Financial Supervision Authority (Komisja Nadzoru Finansowego-KNF) and the Financial Ombudsman. The linguistic analysis on its own is, naturally, not sufficient to evaluate the overall level of complexity and comprehensibility of the agreements (the difficulty in terms of substantive contents cannot be assessed), but it may constitute a reference point and an essential aid in wording the provisions of such agreements in the future (Chłon-Domińczak, Góra, Rutecka, 2016b).

Table 2. The level of comprehensibility of selected IKE and IKZE agreements offered on the Polish market

\begin{tabular}{|l|c|c|}
\hline & Class of text difficulty & $\begin{array}{c}\text { FOG index } \\
\text { (FOG Index, textual) }\end{array}$ \\
\hline IKE general terms and conditions of insurance & $5 / 7$ & $13.8-15.1$ \\
\hline IKZE general terms and conditions of insurance & $5 / 7$ & $13.4-14.9$ \\
\hline General terms and conditions of VPF agreement & $4 / 7$ & $11.6-11.7$ \\
\hline
\end{tabular}

Key:

Class of text difficulty: 1 -childish (1-3 grade of primary school), 2-very easy (grades 3-6 of primary school), 3-easy, comprehensible for an average Pole (junior school level), 4-slightly more difficult, comprehensible for people with secondary education or having substantial life experience (secondary school), 5-more difficult, comprehensible for educated people (bachelor's degree/ engineering studies), 6-difficult to read for an average Pole (master studies), 7-very complicated, professional, specialist knowledge required to understand the text (doctoral studies or specialisation in a given field).

The FOG index informs about the number of years of education required to understand a text. The analysis was carried out on the basis of general terms and conditions of insurance for IKE, IKZE and VPF offered by selected financial institutions (Aviva TUnŻ S.A., Metlife PTE S.A., PZU Życie S.A., PTE PZU S.A.), using the JASNOPIS application.

Source: Chłon-Domińczak, Góra, Rutecka, 2016b.

The difficulty of the contractual language and negative experience involved in reading the incomprehensible documents, which defines the manner of product operation may give rise to an unwillingness to read agreements in the future, and consequently to resignation from purchasing additional pension products or to the conclusion of inadequate agreements (mis-selling). This may also be the reason why consumers indicate the media, direct contact with the Social Insurance Institution (Zaktad Ubezpieczeń Spotecznych-ZUS) or opinions of their acquaintances as the main source of information about supplementary pension systems (ZUS, 2016; Lewicka-Strzałecka, 2016). They do not perceive the documents, which underlie the provisions of agreements, 
the official statistics or legal regulations as an adequate and comprehensible source of information.

It is worth pointing out that the consumers in the Polish market find the offers of financial institutions unreliable (Lewicka-Strzałecka, 2016). Most clients believe that they are purposefully misled, that representatives of financial institutions conceal unfavourable aspects of contracts and that "catches" and understatements are used. Only a slightly better opinion about the use of such provisions was expressed by respondents of the banking sector research carried out by TNS Polska in 2014: 18\% of the respondents said that banks did not use "catches" and understatements in the agreements offered (TNS Polska, 2014).

Making decision on supplementary pension products is additionally hindered by the bundle sale (e.g. additional options in insurance agreements, combining the offers of bank deposits and investment/insurance funds), lack of transparency in respect of effectiveness and cost types and levels. Problems with satisfying the need for information among supplementary pension scheme participants are additionally worsened by the fact that the regulatory authority, the legislator and the financial institutions seem to assume that the customer should not have access to full, comprehensive and comparable data about pension products. This aspect was not addressed in any of the legal regulations passed. For example, the regulations currently in force indicate that it is the insurance company that evaluates the situation, the competencies and needs of the customers and selects the relevant financial products for them (Ustawa $z$ dnia 11 września $2015 \mathrm{r}$. $o$ działalności..., art. 21). The client is not expected to do it. This situation does not contribute to building insurance and pension awareness. No efforts are made to ensure transparency and comprehensibility of the product, and the obligations to inform the client are replaced by the necessity to consult financial institutions. The information policy adopted on the pension market focuses primarily on the needs of the supervision authorities, public institutions as well as the requirements of macro analyses, both domestic and international. As a consequence, an individual participant of pension schemes faces an enormous information gap.

\section{Information policy on the supplementary pension market}

The information policy on the third pillar pension market involves relatively insignificant obligations, chiefly pertaining to the regular filing of reports with the regulatory authority. Financial institutions must inform about the composition of the investment portfolio, the value of assets and liabilities, the number of operated schemes, and the number, age and sex of savers, as well as the value of contributions and withdrawals from each form of supplementary pension schemes. They are not obligated to comprehensively inform about products before these are launched on the market. Consequently, the third pillar products are not certified in any way in terms of the proposed financial mechanism, usefulness for the purpose of long-term saving, and risk level, or the expected investment effectiveness and fees. Additionally, the supervisory authority only publishes aggregated information 
about the market with a list of financial institutions, which operate thereon. The list of available pension products is not published and neither are their core characteristics and investment results. This does not help individual savers move around the market, and they must obtain the information necessary to select and evaluate the pension agreements on their own. Financial institutions provide potential savers with information about the products offered before the conclusion of an agreement, but the form of such information is neither comprehensible nor comparable for an average Pole. Information provided to individuals before the conclusion of an agreement can be found in various documents underlying the provisions of the agreements. These are frequently documents, which describe not only the financial product (e.g. the general terms and conditions of insurance, information prospectuses, key information on products), but also, more elaborately, the rules of operation of financial institutions (statutes, rules for service provision, memoranda, conditions of the issue). Presented below is a list of obligatory documents handed over to potential buyers of individual pension schemes (IKE and IKZE) depending on the type of financial institution (Table 3).

Table 3. Documents handed out to potential IKE and IKZE buyers before conclusion of agreements

\begin{tabular}{|c|c|c|c|c|c|}
\hline & \multicolumn{5}{|c|}{ Type of financial institution } \\
\hline & ZUṅ் & TFI & Bank & $\begin{array}{c}\text { Brokerage } \\
\text { house }\end{array}$ & PTE \\
\hline 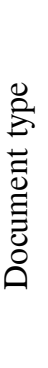 & $\begin{array}{l}\text { - } \text { general terms } \\
\text { and conditions } \\
\text { of insurance } \\
\text { with appendices } \\
\text { - product sheet } \\
\text { - terms and } \\
\text { conditions of } \\
\text { unit-linked } \\
\text { funds }\end{array}$ & $\begin{array}{c}\text { - essential } \\
\text { information } \\
\text { for investors } \\
\text { - information } \\
\text { prospectus } \\
\text { (including } \\
\text { the Statutes) }\end{array}$ & $\begin{array}{l}\text { - terms and } \\
\text { conditions of } \\
\text { maintaining } \\
\text { accounts with } \\
\text { appendices }\end{array}$ & $\begin{array}{l}\text { - terms and } \\
\text { conditions } \\
\text { of brokerage } \\
\text { services with } \\
\text { appendices }\end{array}$ & $\begin{array}{l}\text { - information } \\
\text { prospectus } \\
\text { (including } \\
\text { the Fund } \\
\text { Statutes) }\end{array}$ \\
\hline
\end{tabular}

Source: own elaboration.

For products offered by an insurance company the general terms and conditions of insurance (GCI) is the essential document, whose scope is specifically defined in the Insurance and Reinsurance Activity Act of 2015 (Ustawa z dnia 11 września 2015 r. o działalności...).

They should be written in a language, which is unambiguous and comprehensible for the policyholder. If any doubts arise or unclarities exist, they are interpreted in favour of the policyholder. However, the practice does not conform to the regulations, which seems to be confirmed by the outcome of research on the difficulty of the language used in such documents. Thus, as long as the supervisory authority does not verify compliance 
with the statutory requirements (and impose sanctions for their breach), this provision will remain a dead letter. Pursuant to the Guidelines for insurance companies regarding insurance distribution (KNF, 2014, recommendation 7), with respect to insurance products, the insurance company should also develop the so-called key information on product (karta produktu), which is not, however, an integral part of the agreement. The document must include the purpose of the product, its characteristics, explanation of the mechanism of operation of the product offered, its functions and application as well as information about the investment risk and possible losses. This document is certainly more frequently and willingly read by the potential servicer recipients, as it usually consists of a few pages and is frequently presented in tabular form.

With respect to IKE/IKZE agreements with investment fund companies, the potential buyer receives the statutes of the funds, key information for investors, and the information prospectus, with the set of offer-related documents, which differ depending on the type of the fund (Siwek, Wojakowski, 2016, p. 39).

The key information for investors is the most concise document (in this respect, they are similar to the key information on insurance product) made in a strictly defined format. It contains the minimum scope of information about the fund to be familiarised with so as to make an informed investment. This includes, among other things, the investment policy of the fund, its hitherto results, costs and risks involved in the investment. The information contained in the documents is supplemented in the information prospectus for the fund (which also includes the statutes), the annual and semi-annual financial statements of the fund (sub-fund), and with respect to SFIO (subfundusz inwestycyjny otwarty): the information for clients of an alternative investment fund (Siwek, Wojakowski, 2016, p. 24).

For banks and brokerage houses, the potential buyer of the financial services receives the general terms and conditions of maintaining the accounts with a table of fees and commissions as well as the interest rate table (with respect to banks). It happens that the standard terms and conditions are accompanied with additional conditions of the contract concluded on a promotional basis.

With respect to agreements concluded with Pension Societites (powszechne towarzystwa emerytalne-PTE) for IKE or IKZE in the form of a voluntary pension fund (VPF; dobrowolne fundusze emerytalne-DFE), the client declares that he is familiar with the information prospectus including the statutes of the fund, information about the results of investment activities and the approved annual financial statements of the fund (Ustawa $z$ dnia 28 sierpnia 1997 r. o organizacji..., art. 189).

The aforesaid documents provided by financial institutions differ in format, language and layout. Additionally, the documents are quite sizeable and their language is specialised, which considerably hinders their understanding and comparison. Most financial institutions are obliged to post them on their websites, so that before choosing a specific product, and contacting the selected institution, each client can compare the conditions of contracts, with no pressure from a representative of the financial institution. 
The information policy of the financial institutions is also very limited at the stage of the performance of IKE and IKZE agreements. The obligations to inform and the scope of data provided to the savers are rarely defined in the legal regulations, and much more frequently they are subject to procedures established by the financial institutions themselves. The saver usually gets information on an account balance at least once a year, with the majority of pension product providers offering online access to IKE/ IKZE accounts.

The life insurance company is obliged to inform about the level of benefits at least once a year, if the said values change throughout the effective term of the agreement (Ustawa z dnia 11 września 2015 r. o dziatalności..., art. 20 (3)). The frequency of informing about the balance of savings is similar with respect to accounts maintained by investment fund companies. In this case, the information applies to all funds in which contributions paid to IKE/IKZE by an individual are invested.

In banks and brokerage houses, the client usually has constant access to account information, and the institutions which maintain the accounts are not obliged to deliver the balance statements with any specified frequency. The summary information is provided once an instrument is sold, an account is closed and funds are withdrawn/ transferred. However, the client is informed about the amount of resources paid in and out and transactions recorded on the account with no indication of the rate of return (gross and net) yielded by the invested funds throughout the effective term of the agreement.

With respect to VPF, the fund sends to each member, at regular intervals but at least every twelve months, a statement of funds deposited on the account, dates of contributions and transfer payments made during this period, and conversion of the contributions and transfer payments into accounting units, the results of the fund investing activity, as well as the rules of the investment policy and the investment objective of the fund, together with indices to which the rates of return accomplished by the fund are compared.

With respect to all the listed forms of individual pension schemes, the saver is informed about the account balance, contributions paid and transactions recorded at the beginning and end of the reporting period. Usually, however, the saver does not get full information about the total sum of contributions made and fees deducted (an aggregate one), the rate of return on investment activity (except for voluntary pension funds), the profit accomplished (nominal and real) or the effective rate of return on the investment (including inflation and fees).

\section{The information gap}

The decision to select or change a pension product should be preceded with an analysis of the most essential (from the saver's perspective) qualities of the products offered. Currently, the regulatory authority (KNF) regularly publishes the following scope of information about the operation of the third pillar: 1) the 
number of schemes/accounts in each form, 2) the list of institutions offering pension accounts, 3) payments to accounts and accumulated assets (average and aggregated), 4) age and sex of the savers, 5) the number of withdrawals, transfer withdrawals and returns.

None of the listed information is useful in the process of selection and assessment of a pension product by the individual saver. To take an informed decision, the saver needs quite different information, the most essential of which includes: a) the list of products on offer and their basic qualities, b) the amount of minimum contribution and the frequency of its payment, c) the level of costs in each product, d) the guarantees limiting the risk, e) information about the investment policy/interest rate and hitherto results on the financial instrument, including nominal and real results. Obviously, some of the information can be found in the terms and conditions of services provided by providers, but it is presented in a complex, incomprehensible manner, preventing comparison.

The lack of essential and comprehensible information and especially the absence of a list of pension products comparable in terms of the said features, sets out the general frames of the information gap, which is observed on the supplementary pension market in Poland. The gap poses an essential threat to the operation of the third pillar: no transparency of the supplementary pension market will be conducive to low pension awareness and low level of universality (participation). No basic knowledge about the operation of pension funds may result in suboptimal choices, redistribution towards financial institutions and ineffectiveness of the entire supplementary pension system. In a situation where none of the institutional participants of the pension market is interested in publishing the information about effectiveness and costs of each of the products, the market will offer products, which fail to meet the clients' expectations, and those interested in them will move their funds to more effective solutions, because of unavailability of information identifying the products.

\section{Conclusions}

The evaluation of the supplementary pension insurance in Poland poses a problem from the perspective of an individual saver. The operation of pension plans can currently be assessed only by evaluating the collective data on market growth, the number of schemes, the number of their participants and the assets accumulated therein. "Universality" is assessed, while transparency, comprehensibility, adequacy or effectiveness of the products offered are disregarded. The needs of the savers have been ignored at the stage of design and implementation of the requirements for the information policy. The pension contracts are not only complex in terms of the description of financial mechanisms, investment risk, the fees charged, but they are also written in incomprehensible language. The information provided to individual savers is incomplete, non-comparable and difficult to access, which may lead to sub-optimal decisions, mis-selling and offering ineffective products. 
The proper development of supplementary pension system in Poland needs deep changes in information policy. A major challenge is to ensure full comprehensibility of the information provided to pension product recipients, both at the stage of the conclusion of the agreement and execution of its provisions. Even the most comprehensive information is useless if is unreadible. The regulatory body should enforce the obligations of clarity and comprehensibility, stipulated in the laws. Some linguistic tools should be employed to assess the provisions of agreement addressed to individuals on a broader basis, and sanctions should be imposed for agreements which are totally incomprehensible. Such agreements should be eliminated from the market.

The most essential information, which is not regularly communicated to an individual saver at the moment, is the information about the costliness and investment effectiveness of pension schemes. Each financial institution should regularly calculate and publish the ratio of overall cost incurred by the client during a saving period. They should also regularly inform the clients about nominal and real rates of return (including fees charged) as well as the nominal and real amount of profit/loss over the total saving period.

Information about investment results and costs should also be sent to the regulatory authority so that it can publish a list of pension products offered on the Polish market and provide savers with information required to select a product and assess its operation. Such a list could also be available on websites of other institutions: Financial Ombudsman or the Ministry of Family, Labour and Social Policy.

\section{References}

Allgayer, S. et al. (2016). Pension Savings: The Real Return. 2016 Edition. Brussels: Better Finance.

Berthon, J. et al. (2014). Pension Savings: The Real Return. 2014 Edition. Brussels: Better Finance.

Broda, B., Ogrodniczuk, M., Nitoń, B., Gruszczyński, W. (2014). Measuring Readability of Polish Texts: Baseline Experiments. In: N. Calzolari et al. (eds), Proceedings of the Ninth International Conference on Language Resources and Evaluation (LREC14). Reykjavik: ELRA.

Chłon-Domińczak, A., Góra, M., Rutecka, J. (2016a). Efektywność i przejrzystość systemu emerytalnego z uwzględnieniem otwartych funduszy emerytalnych. Warszawa: IGTE.

Chłoń-Domińczak, A., Góra, M., Rutecka, J. (2016b). Jakie zmiany regulacyjne moglyby wptynąć na podniesienie poziomu przyszlych świadczeń emerytalnych? Warszawa: IGTE.

European Commission (2010). Private pension schemes - their role in adequate and sustainable pensions. Brussels.

Góra, M., Rutecka, J. (2013). Elastyczny system emerytalny a obecne i przyszłe potrzeby jego uczestników. Ekonomista, no. 6. 
Instytut Wolności i Raiffeisen Polbank (2014). Stan wiedzy ekonomicznej Polaków. Warszawa.

Klages, M., Viver, J.M. (2015). Pension Savings. The Real Return. 2015 Edition. Brussels: Better Finance.

KNF (2014). Wytyczne dla zakładów ubezpieczeń dotyczące dystrybucji ubezpieczeń. Warszawa: UKNF.

Lewicka-Strzałecka, A. (2016). Moralność finansowa Polaków. Raport z badań. GdańskWarszawa: Konferencja Przedsiębiorców Finansowych w Polsce.

OECD (2012). OECD Pension Outlook 2012. Paris: OECD Publishing.

OECD (2015). Pensions at Glance 2015. Paris: OECD Publishing.

Oxera (2013). Study on the position of savers in private pension products. Brussels: Oxera Consulting Ltd.

Paklina, N. (2016). The role of Supervision Related to Consumer Protection in Private Pension Systems. IOPS Working Papers on Effective Pensions Supervision, no. 27.

Pisarek, W. (1969). Jak mierzyć zrozumiałość tekstu? Zeszyty Prasoznawcze, no. 4.

Prast, H., van Soest, A. (2015). Pension Awareness, Pension Communication, and Choice Architecture. Netspar \& Tilburg University.

Rajnes, D. (2003). International Evidence: Development and Delivery of Financial/Investment Information to the Public. Social Security Administration.

Rutecka, J. (ed.) (2014). Dodatkowy system emerytalny w Polsce-diagnoza i rekomendacje zmian. Warszawa: Towarzystwo Ekonomistów Polskich.

Siwek, A., Wojakowski, K. (2016). Jednostki uczestnictwa i certyfikaty inwestycyjne funduszy inwestycyjnych — porównanie zagadnień prawnych i organizacyjnych. Poradnik klienta ustug finansowych. Warszawa: UKNF.

Szumlicz, T., Żukowski, M. (eds) (2004). Systemy emerytalne w krajach Unii Europejskiej. Warszawa: Twigger.

TNS Polska (2014). Wizerunek polskiego sektora bankowego. Edycja 2014. Warszawa: ZBP.

Turner, J.A. (2013). Pension investors: complexity in advisory fee disclosures. In: M. Szczepański (ed.), Pension Reforms-Comparison and Evaluation. Poznań: Publishing House of Poznan University of Technology.

Ustawa z dnia 11 września 2015 r. o działalności ubezpieczeniowej i reasekuracyjnej, Dz. U. z 2015 r., poz. 1844.

Ustawa z dnia 20 kwietnia 2004 r. o indywidualnych kontach emerytalnych oraz indywidualnych kontach zabezpieczenia emerytalnego, Dz. U. z 2016 r., poz. 1776.

Ustawa z dnia 28 sierpnia 1997 r. o organizacji i funkcjonowaniu funduszy emerytalnych, Dz. U. z 2017 r., poz. 870. 
Potrzeby, możliwości i problemy ewaluacji dodatkowych planów emerytalnych z punktu widzenia indywidualnego odbiorcy

Streszczenie

Celem artykułu jest identyfikacja zakresu informacji (ilościowych i jakościowych) dotyczących produktów emerytalnych niezbędnych do dokonania oceny ich funkcjonowania przez indywidualnych oszczędzających, a następnie porównanie tego zakresu z publikowanymi obecnie danymi o dodatkowym rynku emerytalnym oraz informacjami przekazywanymi klientom przez instytucje finansowe. Badanie oparto na analizie dostępnej literatury, dokumentów i raportów instytucji emerytalnych oraz aktów prawnych regulujących system emerytalny i rynek finansowy. Na podstawie przeprowadzonej analizy w ostatniej części artykułu wskazane zostały możliwości dalszych zmian w polityce informacyjnej oraz występujące ograniczenia, które wynikają z charakteru oferowanych produktów oraz poziomu skomplikowania systemów dodatkowych.

Słowa kluczowe: system emerytalny, dodatkowe zabezpieczenie emerytalne, pracownicze programy emerytalne, indywidualne konta emerytalne, indywidualne konta zabezpieczenia emerytalnego 